\title{
Use of Learning CD Media to Improve Student Motivation and Mathematics Learning Outcomes
}

\section{Penggunaan Media CD Pembelajaran Untuk Meningkatkan Motivasi dan Hasil Belajar Matematika}

\author{
Budiono (*) \\ SD Negeri 1 Karanganyar \\ Jl. Raya Karanganyar-Batur KM 1, Purbalingga, Jawa Tengah
}

Received: April 9, 2018

Revised: July 2, 2018

Accepted: July 11, 2018

\begin{abstract}
Learning CD Media is a systematically designed media that can attract students. The use of learning CD media can improve the motivation and the learning outcomes of mathematics on determining the various simple wake-up nets for students of SD Negeri 1 Kalijaran. The purpose of this study is to find out how much improvement of motivation and student learning outcomes about determining various simple wake-up nets using learning CD media. Research is a classroom action research consisting of 4 stages (planning, implementation, observation, and reflection) in two cycles. Data collection techniques used are the test techniques, data retrieval tests before and after the action are held using the CD learning media. The method used in this research is classroom action research with data collection technique through observation, interview, and documentation. The results of the research cycle I showed 7 students $(53.8 \%)$ achieve mastery learning, which has not completed 6 students $(46.2 \%)$. The average value of students increased from pre-cycle 58.46 to 69.61. Cycle II there are 13 students (100\%) achieve learning mastery. The average value of cycle II students increased from cycle I 69.61 to 84.62 . Based on the observation, students also experienced an increase in learning motivation in the first cycle of 75.4 percent to 94 percent in cycle II. The conclusion of the study that the use of learning CDs can improve the motivation and learning outcomes of students of grade V SD Negeri 1 Kalijaran second semester Year of Study 2015/2016.
\end{abstract}

Keywords: CD Media, mathematics, motivation, learning outcomes.

(*) Corresponding Author: ～～budiono19671215@gmail.com, hp: 081326647117.

How to Cite: Budiono, B. (2018). Use of learning CD media to improve student motivation and mathematics learning outcomes. Formatif: Jurnal Ilmiah Pendidikan MIPA, 8 (2): 101-110. http://dx.doi.org/10.30998/formatif.v8i2.2459

\section{PENDAHULUAN}

Tidak sedikit di antara guru masih cenderung menggunakan pendekatan konvensional di dalam melaksanakan proses belajar mengajar. Guru hanya mengandalkan pada sebuah metode ceramah untuk mentransfer pengalaman kepada siswa. Siswa dianggap botol kosong yang siap saji, diisi segala macam bentuk informasi tanpa memedulikan perkembangan secara mental dan fisik. Pada sisi yang lain banyak di antara mereka tidak menggunakan alat peraga ketika melakukan proses pembelajaran. Pembelajaran berjalan apa adanya. Hal ini, tentu akan menghambat proses belajar untuk 
Formatif: Jurnal Ilmiah Pendidikan MIPA

Vol. 8, No. 2, Agustus 2018, pp. 101-110

p-ISSN: 2088-351X

e-ISSN: 2502-5457

DOI: http://dx.doi.org/10.30998/formatif.v8i2.2459

mencapai hasil dan prestasi yang diharapkan. Sesuai uraian tersebut, dilakukan refleksi diri dengan merenung dan mengingat kembali untuk menemukan kesalahan-kesalahan yang sering dilakukan dalam proses pembelajaran selama ini, khususnya pada mata pelajaran matematika.

Guru perlu mengubah metode yang kreatif dan inovatif agar pembelajaran matematika disukai siswa. salah satunya yaitu dengan memamfaatkan media CD pembelajaran. Media pembelajaran memiliki manfaat khusus yang dapat kita jadikan pertimbangan sebagai subjek penelitian, di antaranya (1) Penyampaian materi dapat diseragamkan, (2) Proses pembelajaran menjadi lebih menarik, (3) Proses belajar siswa dan mahasiswa lebih interaktif, (4) Jumlah waktu belajar mengajar dapat dikurangi, (5) Kualitas belajar siswa dan mahasiswa dapat ditingkatkan, (5) Proses belajar dapat terjadi di mana saja dan kapan saja, (6) Peran guru, dosen dapat berubah ke arah yang lebih positif dan produktif (Handhika, 2012). Media pembelajaran visual yang interaktif ini akan mendapatkan perhatian yang serius oleh siswa (Astuti, 2018). Arsyad (2000) mengemukakan bahwa pemakaian media pembelajaran mampu membangkitkan keinginan, minat, motivasi, dan rangsangan kegiatan belajar, bahkan membawa pengaruh psikologis terhadap siswa. Penggunaan media juga akan sangat membantu meningkatkan efektivitas pembelajaran.

Proses belajar siswa dan hasilnya merupakan parameter dan tolak ukur bermutu atau tidaknya pengelolaan suatu pendidikan, sedangkan pendidikan yang bermutu sangat dipengaruhi oleh kemampuan, profesionalisme, sikap guru di dalam mengaktualisasikan tugas dan tanggung jawabnya sebagai pribadi yang profesional. Tinggi rendahnya mutu pendidikan bergantung pada sikap mental dan kesungguhan guru ketika mengembangkan kemampuan profesinya untuk mengasah dan mengolah potensi anak didik agar berkembang secara optimal untuk mewujudkan tujuan yang telah direncanakan. kemudian untuk mencapai hasil belajar yang maksimal, tidak terlepas dari proses belajar mengajar. Adapun dalam proses belajar mengajar banyak dipengaruhi oleh faktor pendidik, anak didik, kurikulum, alat, dan faktor lingkungan (Bhakti, 2017).

Pembelajaran matematika adalah proses pemberian pengalaman belajar kepada siswa melalui serangkaian kegiatan yang terencana sehingga peserta didik memperoleh kompetensi tentang bahan matematika. Kegunaan matematika bukan hanya memberikan kemampuan dalam perhitungan-perhitungan kuantitatif, tetapi juga dalam penataan cara berpikir terutama dalam pembentukan kemampuan menganalisis, membuat sintesis, melakukan evaluasi hingga kemampuan memecahkan masalah serta menerapkannya pada kehidupan sehari-hari (Sahrudin, 2014). Mengukur keberhasilan pembelajaran matematika dapat dilihat dari kemampuan siswa berkomunikasi dengan menggunakan bilangan dan simbol-simbol serta ketajaman penalaran yang dapat membantu memperjelas dan menyelesaikan permasalahan dalam kehidupan sehari-hari dengan menggunakan tes hasil belajar. Matematika dapat menjembatani ilmu sains lainnya yang berhubungan dengan proses perhitungan.

Dari hasil observasi mata pelajaran Matematika dengan materi pokok menggambar dan membuat jaring-jaring bangun ruang sederhana dapat diuraikan sebagai berikut. Dari 13 siswa yang belum tuntas sebanyak 9 siswa atau mencapai angka 69\%, dengan KKM matematika 63. Siswa yang telah dinyatakan tuntas sebanyak 4 siswa atau baru $31 \%$. Perbandingan antara siswa yang sudah tuntas dengan siswa yang belum tuntas masih lebih besar yang belum tuntas. Berdasarkan data tersebut dapat dilihat bahwa siswa yang masih di bawah tuntas sebanyak 9 siswa dengan nilai rata-rata kelas adalah 58,46, masih di bawah nilai rata-rata ketuntasan $75 \%$ dan dinyatakan perlu dilanjutkan dengan tindakan perbaikan. 
Formatif: Jurnal Ilmiah Pendidikan MIPA

Vol. 8, No. 2, Agustus 2018, pp. 101-110

p-ISSN: 2088-351X

e-ISSN: 2502-5457

DOI: http://dx.doi.org/10.30998/formatif.v8i2.2459

Motivasi belajar siswa SD N 1 Karanganyar kelas IV juga tergolong rendah. setiap pembelajaran matematika terlihat mayoritas siswa tidak aktif mengikuti KBM, ada yang tidak mengerjakan tugas, ada yang tertidur di kelas, dan ada juga yang tidak membawa buku pelajaran. Hal ini menyebabkan hasil belajar siswa juga rendah. Motivasi merupakan dorongan setiap individu untuk melakukan sesuatu. Menurut Santrock (2014) motivasi merupakan proses yang memberikan energi, mengarahkan, dan mempertahankan perilaku. Motivasi belajar siswa akan memengaruhi hasil belajar siswa juga. Biasanya siswa yang memiliki motivasi belajar rendah akan berdampak pada rasa malas untuk belajar, keaktifan berkurang, serta hasil belajar juga rendah. Seseorang yang memiliki minat terhadap kegiatan tertentu cenderung memberikan perhatian yang besar terhadap kegiatan tersebut (Siagian, 2012).

Penelitian yang dilakukan oleh Apriyani (2017) mengenai pengaruh penggunaan media proyeksi terhadap hasil belajar matematika menjelaskan bahwa penggunaan media proyeksi mampu menciptakan proses pembelajaran yang merangsang pikiran, motivasi, minat, dan perhatian siswa. Dengan begitu, memudahkan siswa memahami pembendaharaan kata, menghadirkan objek yang sulit dihadirkan dalam bentuk aslinya, mampu memberikan rangsangan yang sama, mempersamakan pengalaman, dan menimbulkan persepsi yang sama. Dan hasil penelitiannya menunjukkan bahwa terdapat pengaruh penggunaan media proyeksi terhadap hasil belajar matematika pada bangun ruang sisi datar. Hal ini menunjukkan bahwa media pembelajaran mampu meningkatkan hasil belajar siswa.

Berdasarkan latar belakang di atas, peneliti menerapkan CD pembelajaran matematika untuk meningkatkan motivasi dan hasil belajar matematika. CD pembelajaran merupakan salah satu bentuk media pembelajaran yang dapat diterapkan dalam pembelajaran di sekolah. CD pembelajaran dapat berupa video maupun animasi pembelajaran yang dapat menarik siswa dalam belajar sehingga siswa termotivasi dan aktif belajar.

\section{METODE}

Penelitian ini merupakan Penelitian Tindakan Kelas (PTK), yang terdiri dari empat tahap yaitu perencanaan (planning), pelaksanaan (act), pengamatan (observe), dan refleksi (reflection). Subjek dalam penelitian ini adalah seluruh siswa kelas V SD N 1 Kalijaran semester genap tahun ajaran 2015/2016 berjumlah 13 siswa, yang terdiri dari 10 siswa laki-laki dan 3 siswa perempuan. Instrumen dalam penelitian ini yaitu lembar pelaksanaan pembelajaran, lembar angket motivasi belajar dan lembar soal tes evalausi. Lembar motivasi terdiri dari 5 butir pernyataan. Soal tes evaluasi berupa soal tertulis pilihan ganda dengan jumlah soal sebanyak 10.

Langkah-langkah dalam penelitian ini di antaranya tahap pertama yaitu perencanaan. Dalam tahap perencanaan guru menyiapkan instrumen pembelajaran (RPP dan silabus) dan instrumen penelitian (lembar motivasi belajar dan lembar soal evaluasi). Tahap selanjutnya adalah tindakan atau aksi. Tanpa tindakan rencana tinggallah sebuah rencana hanya angan-angan belaka. Dalam tahap tindakan pembelajaran dilakukan dengan $C D$ pembelajaran yang berisi animasi matematika mengenai menggambar dan membuat jaring-jaring bangun. Tahap ketiga PTK adalah tahap pengamatan, yakni melakukan pengamatan dan menemukan hal-hal yang harus diperbaiki sesuai dengan rencana. Setelah pengamatan dilakukan, hasilnya didiskusikan dengan teman sejawat untuk melakukan tahap berikutnya yaitu refleksi. Refleksi dilakukan pada tahap keempat, dimaksudkan untuk mengetahui dampak proses pembelajaran baik kekurangan maupun 
Formatif: Jurnal Ilmiah Pendidikan MIPA

Vol. 8, No. 2, Agustus 2018, pp. 101-110

p-ISSN: 2088-351X

e-ISSN: 2502-5457

DOI: http://dx.doi.org/10.30998/formatif.v8i2.2459

kelebihan pembelajaran tersebut. Dengan demikian dapat mengenal kekurangan, kekuatan, dan kelemahan dari tindakan yang dilakukan. Hasil dari refleksi akan dijadikan dasar untuk melakukan tindakan berikutnya. PTK merupakan proses pengkajian berdaur, maka tindakan selanjutnya harus kembali melalui empat tahap.

Teknik pengumpulan data dalam penelitian ini adalah metode tes dan metode observasi. Metode tes untuk mengetahui hasil belajar siswa, sedangkan metode observasi untuk mengetahui motivasi belajar siswa. Hasil belajar siswa dinilai melalui tes evaluasi dengan persamaan berikut,

$$
\text { Nilai }=\frac{\text { Jumlah jawaban benar }}{\text { Jumlah soal }} \times 100
$$

Nilai rata-rata kelas

$$
\bar{x}=\frac{\sum x}{N}
$$

Keterangan :

$x=$ nilai rata-rata kelas

$\Sigma x=$ jumlah seluruh skor

$N=$ banyaknya siswa (Arikunto, 2006)

Untuk mengetahui ketuntasan belajar siswa digunakan rumus:

$$
K B=\frac{T}{T t} \times 100 \%
$$

Keterangan:

$K B$ : Ketuntasan belajar

$T$ : Jumlah peserta didik yang tuntas belajar

$T t$ : Jumlah seluruh peserta didik

Tabel 1. Kiteria Ketuntasan Belajar Siswa

\begin{tabular}{cc}
\hline Interval Skor & Kategori \\
\hline Nilai $\leq 85$ & Siswa tidak tuntas belajar \\
Nilai $\geq 85$ & Siswa didik tuntas belajar \\
\hline
\end{tabular}

Penilaian motivasi belajar peserta didik tiap aspek yang diamati dalam menggunakan rumus:

$$
K R(\%)=\frac{n}{N} \times 100 \%
$$

Keterangan:

$n=$ Jumlah poin karakteristik siswa

$N=$ Jumlah seluruh siswa 
Formatif: Jurnal Ilmiah Pendidikan MIPA

Vol. 8, No. 2, Agustus 2018, pp. 101-110

p-ISSN: 2088-351X

e-ISSN: 2502-5457

DOI: http://dx.doi.org/10.30998/formatif.v8i2.2459

Tabel 2. Kriteria Motivasi Belajar Peserta Didik

\begin{tabular}{ll}
\hline \multicolumn{1}{c}{ Interval Skor } & \multicolumn{1}{c}{ Kategori } \\
\hline $0 \% \leq K R<25 \%$ & Motivasi sangat rendah \\
$26 \% \leq K R<50 \%$ & Motivasi rendah \\
$51 \% \leq N R S<75 \%$ & Motivasi sedang \\
$76 \% \leq N R S<100 \%$ & Motivasi sangat tinggi \\
\hline
\end{tabular}

\section{HASIL DAN PEMBAHASAN}

Hasil

Pada kondisi awal ini peneliti melakukan observasi data dokumentasi nilai matematika sebelum penelitian. Deskripsi hasil belajar siswa pada pra siklus dapat dilihat pada tabel 3 .

Tabel 3. Hasil Belajar Siswa Pra Siklus

\begin{tabular}{lc}
\hline \multicolumn{1}{c}{ Deskripsi hasil belajar siswa } & Pra siklus \\
\hline Nilai rata-rata & 58,5 \\
Nilai maksimal & 70 \\
Nilai minimal & 30 \\
Jumlah siswa yang tuntas & 4 \\
Jumlah siswa yang tidak tuntas & 9 \\
Persentase ketuntasan belajar & $31 \%$ \\
Persentase ketidaktuntasan belajar & $69 \%$ \\
\hline
\end{tabular}

Tabel 3 merupakan data perolehan hasil belajar pada studi awal. Dari 13 siswa yang telah tuntas sebanyak 4 siswa atau mencapai angka $31 \%$. Siswa yang belum tuntas sebanyak 9 siswa atau baru 69\%. Berdasarkan tabel di atas menunjukkan bahwa siswa yang belum tuntas masih lebih besar dua kali dari yang telah tuntas. Berdasarkan data tersebut dapat dilihat bahwa siswa yang telah mencapai nilai di bawah tuntas sebanyak 9 siswa dengan nilai rata-rata kelas adalah 58,46, masih di bawah nilai rata-rata ketuntasan dan dinyatakan perlu dilanjutkan dengan tindakan perbaikan.

Setelah melaksanakan studi awal selanjutnya adalah pelaksanaan siklus I. Siklus ini merupakan langkah perbaikan yang dapat diharapkan ada peningkatan hasil belajar setelah dilakukan sebuah tindakan dengan melakukan perbaikan pembelajaran. Pada tahap perencanaan guru menyiapkan instrumen pembelajaran seperti silabus, RPP, dan instrumen penelitian seperti lembar motivasi belajar serta lembar soal evaluasi. Pada tahap pelaksanaan guru melaksanakan kegiatan pembelajaran menggunakan CD pembelajaran. CD pembelajaran yang digunakan berisi media pembelajaran simulasi mengenai materi menggambar dan membuat jaring-jaring bangun. Pada siklus I diperoleh hasil belajar seperti pada tabel 4 . 
Formatif: Jurnal Ilmiah Pendidikan MIPA

Vol. 8, No. 2, Agustus 2018, pp. 101-110

p-ISSN: 2088-351X

e-ISSN: 2502-5457

DOI: http://dx.doi.org/10.30998/formatif.v8i2.2459

Tabel 4. Hasil Belajar Siswa Siklus I

\begin{tabular}{lc}
\hline \multicolumn{1}{c}{ Deskripsi prestasi belajar siswa } & Siklus I \\
\hline Nilai rata-rata & 69,61 \\
Nilai maksimal & 80 \\
Nilai minimal & 35 \\
Jumlah siswa yang tuntas & 9 \\
Jumlah siswa yang tidak tuntas & 4 \\
Persentase ketuntasan belajar & $69 \%$ \\
Persentase ketidaktuntasan belajar & $31 \%$ \\
\hline
\end{tabular}

Dari hasil tersebut diperoleh persentase ketuntasan belajar matematika sebesar $69 \%$. Hal ini, belum sesuai dengan taraf ketuntasan belajar yaitu $>85 \%$. Nilai rata-rata siswa pada siklus I juga belum sesuai dengan batas tuntas KKM yang seharusnya 75 . Oleh karena itu, perlu dilakukan refleksi dan tindakan pada siklus II. Penilaian motivasi belajar dilakukan melalui observasi. Dari lima aspek motivasi yang berkaitan dengan minat siswa yang diamati diperoleh akumulasi angka sebagai bahan perbandingan pada siklus berikutnya. Hasil tersebut dapat dilihat pada tabel 5 dengan persentase rata-rata motivasi belajar siswa sebesar $75,4 \%$.

Tabel 5. Data Hasil Motivasi Siswa Siklus I

\begin{tabular}{clcc}
\hline No & Aspek & $\begin{array}{c}\text { Jumlah } \\
\text { Anak }\end{array}$ & $\begin{array}{c}\text { Present } \\
\text { ase }(\%)\end{array}$ \\
\hline 1 & Minat siswa untuk mengikuti pelajaran (A) & 13 & 100 \\
2 & Minat siswa untuk menyelesaikan tugas (B) & 10 & 77 \\
3 & Minat siswa untuk bekerjasama dalam kelompok (C) & 8 & 62 \\
4 & Minat siswa untuk bertanya kepada orang lain (D) & 5 & 38 \\
5 & Minat siswa untuk memperhatikan penjelasan guru & 13 & 100 \\
& Jumlah & 49 & 377 \\
& Rata-rata & 9,8 & 75,4 \\
\hline
\end{tabular}

Pada siklus II siswa yang telah tuntas belajar sebanyak 13 siswa atau mencapai angka $100 \%$, sedangkan siswa yang belum tuntas adalah 0 siswa atau tinggal $0 \%$. Artinya pada siklus II ada penambahan jumlah siswa yang telah mencapai ketuntasan belajar dari 9 siswa menjadi 13 siswa. Nilai rata-rata siklus II adalah 84,62 atau $100 \%$ tuntas sesuai yang diharapkan.

Tabel 6. Hasil Belajar Siswa pada Siklus II

\begin{tabular}{lc}
\hline \multicolumn{1}{c}{ Deskripsi hasil belajar siswa } & Siklus II \\
\hline Nilai rata-rata & 84,62 \\
Nilai maksimal & 100 \\
Nilai minimal & 80 \\
Jumlah siswa yang tuntas & 13 \\
Jumlah siswa yang tidak tuntas & 0 \\
Persentase ketuntasan belajar & $100 \%$ \\
Persentase ketidaktuntasan belajar & - \\
\hline
\end{tabular}

Pada siklus II terlihat hasil pengamatan motivasi belajar siswa meningkat seperti yang terlihat pada tabel 7 dengan persentase rata-rata motivasi belajar siswa sebesar $94 \%$. 
Formatif: Jurnal Ilmiah Pendidikan MIPA

Vol. 8, No. 2, Agustus 2018, pp. 101-110

p-ISSN: 2088-351X

e-ISSN: 2502-5457

DOI: http://dx.doi.org/10.30998/formatif.v8i2.2459

Tabel 7. Data Hasil Motivasi Siswa Siklus II

\begin{tabular}{clcc}
\hline \multirow{2}{*}{ No } & Aspek & $\begin{array}{c}\text { Jumlah } \\
\text { Anak }\end{array}$ & $\begin{array}{c}\text { Presentase } \\
(\%)\end{array}$ \\
\hline 1 & Minat siswa untuk mengikuti pelajaran (A) & 13 & 100 \\
2 & Minat siswa untuk menyelesaikan tugas (B) & 13 & 100 \\
3 & Minat siswa untuk bekerjasama dalam kelompok (C) & 12 & 92 \\
4 & Minat siswa untuk bertanya kepada orang lain (D) & 10 & 77 \\
5 & Minat siswa untuk memperhatikan penjelasan guru & 13 & 100 \\
& Jumlah & 61 & 469 \\
& Rata-rata & 12 & 94 \\
\hline
\end{tabular}

\section{Pembahasan}

Pada studi awal guru mengalami kegagalan dalam mencapai persentase ketuntasan yaitu $31 \%$. Hal ini, disebabkan guru tidak menggunakan media pembelajaran, sehingga siswa kurang tertarik untuk mengikuti pembelajaran yang sedang berlangsung. Siklus I perolehan prestasi belajar naik dari nilai rata-rata 58,46 menjadi 69,61. Hal ini, menunjukkan perubahan dan peningkatan hasil belajar pada siklus I. Ketuntasan belajar masih di bawah kriteria ketuntasan yang diharapkan yaitu sebesar $80 \%$, sedangkan pada siklus I hanya mencapai ketuntasan sebesar 54\%. Hasil tersebut merupakan upaya guru dalam melakukan perbaikan dengan mengubah skenario pembelajaran. Sedangkan pada siklus II guru mendorong siswa dengan tetap menggunakan media CD pembelajaran dalam proses kegiatan pembelajaran. Namun mengubah jumlah kelompok belajar dari 3 kelompok menjadi 4 kelompok. Demikian juga jumlah anggota kelompok yang tadinya jumlah anggotanya 4--5 perkelompok menjadi 3--4 siswa perkelompok, ternyata cukup efektif karena meningkatkan nilai rata-rata dari 69,61 dari siklus I menjadi 84,62 pada siklus II. Dengan persentase ketuntasan sebesar 54\% dari siklus I menjadi $100 \%$ pada siklus II.

Pada siklus II pembelajaran Matematika tentang menentukan jaring-jaring bangun ruang dinyatakan telah tuntas. Ketuntasan rata-rata belajar siswa mencapai $100 \%$ di atas ketuntasan yang diharapkan. Perolehan nilai rata-rata seluruh siswa mencapai 84,62 . Nilai di atas nilai rata-rata ketuntasan minimal yang diharapkan 80. Keberhasilan tersebut karena ada upaya perbaikan yang dilakukan yaitu mengupayakan penggunaan media CD pembelajaran untuk membantu dalam memahami materi pelajaran sehingga siswa tertarik dengan pelajaran Matematika. Dengan demikian untuk memperjelas hasil dan perubahan yang telah dicapai di bawah ini disajikan rekapitulasi tingkat ketuntasan belajar siswa dari studi awal sampai siklus II.

Keberhasilan perbaikan yang telah dilakukan menunjukkan bahwa media CD pembelajaran memiliki peranan yang cukup besar dalam mengoptimalkan dan meningkatkan pemahaman siswa terhadap materi bahan ajar serta pencapaian hasil belajar. Berdasarkan data pada tabel 6 ketuntasan yang dicapai ada siklus terakhir mencapai $100 \%$. Angka ini di atas ketuntasan yang diinginkan yaitu $80 \%$ maka dalam perbaikan pembelajaran telah mencapai ketuntasan sesuai dengan harapan dan tujuan perbaikan. Memberi gambaran yang nyata perbandingan hasil ketuntasan belajar disajikan dengan gambar 1 tentang ketuntasan belajar pada kondisi awal, hingga siklus terakhir. 
Formatif: Jurnal Ilmiah Pendidikan MIPA

Vol. 8, No. 2, Agustus 2018, pp. 101-110

p-ISSN: 2088-351X

e-ISSN: 2502-5457

DOI: http://dx.doi.org/10.30998/formatif.v8i2.2459

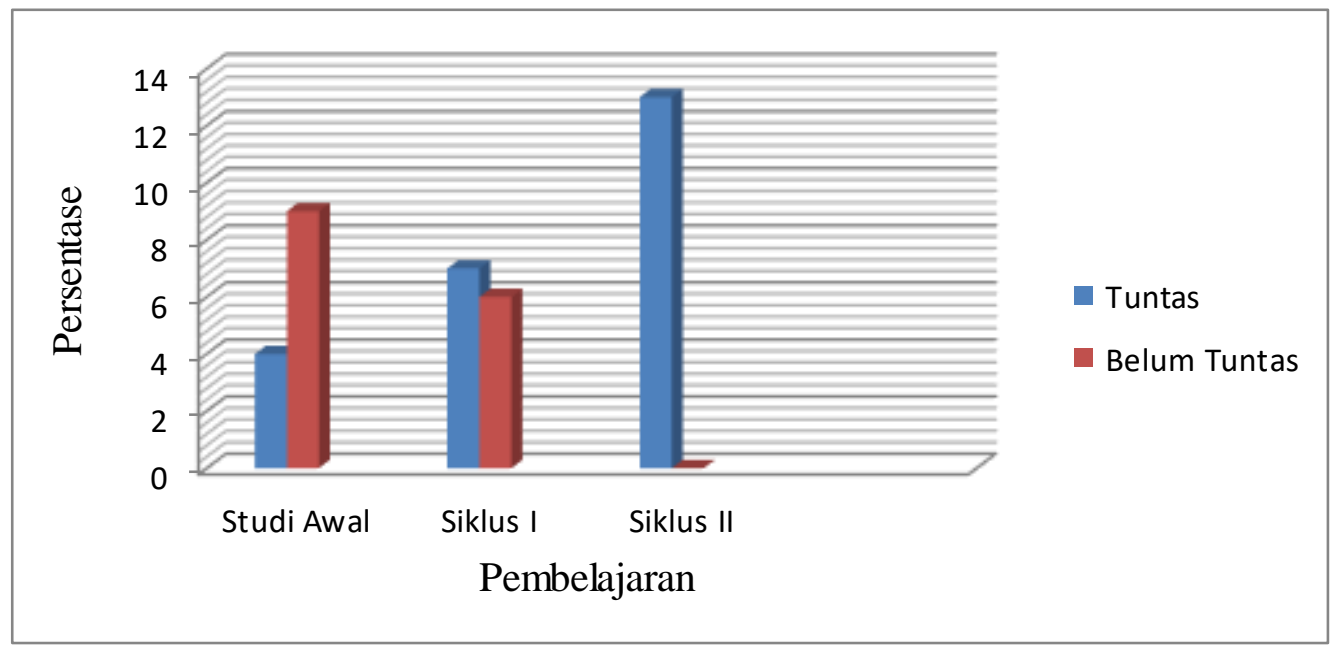

Gambar 1. Grafik Perubahan Ketuntasan Belajar

Peningkatan perubahan kelima aspek motivasi siswa terjadi pada setiap siklus. Perubahan yang sangat mencolok yakni pada siklus II setelah guru memberikan motivasi dan rangsangan dengan tetap menggunakan media $\mathrm{CD}$ pembelajaran yang memadai dan kelompok belajar dengan jumlah anggota yang lebih sedikit sehingga siswa terdorong keinginannya untuk berbuat dan bertindak lebih aktif.

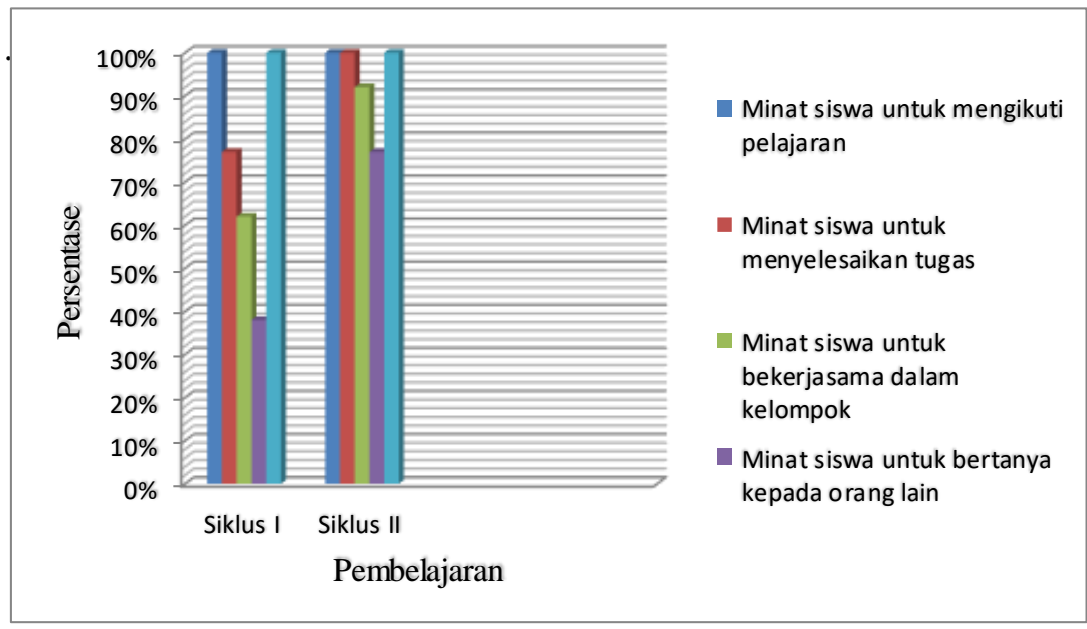

Gambar 2. Grafik Peningkatan Motivasi Siswa

Berdasarkan gambar 2, dapat disimpulkan bahwa siswa aktif mengikuti pembelajaran dengan menggunakan media CD pembelajaran pada setiap siklus pembelajaran, siswa semakin meningkat hingga mencapai $100 \%$. Keadaan semacam ini membuktikan bahwa media CD pembelajaran memiliki peranan yang sangat penting untuk mendorong dan membangun semangat belajar siswa sehingga termotivasi untuk mengambil peran secara aktif di dalam kegiatan belajar dan mengajar. CD pembelajaran berisi tentang animasi matematika materi menggambar dan membuat jaring-jaring bangun ruang sederhana. Siswa terlihat antusias belajar dengan menggunakan CD pembelajaran karena mereka baru pertama kali belajar dengan menggunakan teknologi. Siwa menjadi aktif dalam belajar matematika sehingga motivasi belajar siswa juga meningkat. Hal ini dapat memengaruhi hasil belajar siswa juga menjadi lebih baik lagi. 
Formatif: Jurnal Ilmiah Pendidikan MIPA

Vol. 8, No. 2, Agustus 2018, pp. 101-110

p-ISSN: 2088-351X

e-ISSN: 2502-5457

DOI: http://dx.doi.org/10.30998/formatif.v8i2.2459

Sejalan dengan penelitian Safitri dkk (2017) bahwa media pembelajaran interaktif dengan komputer mampu membangkitkan minat belajar siswa sehingga akan memengaruhi tingkat berpikir kritis siswa dalam menghadapi permasalahan matematika. Media pembelajaran mampu menjembatani antara siswa dan guru dalam proses pembelajaran (Wulandari, 2013). Dengan media pembelajaran yang diberikan ke siswa, rasa ingin tahu siswa akan bertambah. Apalagi siswa SD yang daya interaksi dan keingintahuannya tinggi, yang biasanya belajar di kelas dengan metode ceramah atau diskusi kini diubah dengan strategi yang inovatif yaitu dengan penggunaan media pembelajaran maka akan membuat ketertarikan dan minat siswa.

Media merupakan sarana yang dipakai untuk menyampaikan informasi. Dengan demikian, media pembelajaran merupakan sarana yang dipakai untuk menyampaikan informasi berupa pelajaran agar menarik perhatian siswa. Media pembelajaran memungkinkan informasi yang diberikan lebih akurat dan kekinian, dengan media pula proses pembelajaran akan lebih aktraktif dan dapat memotivasi dalam belajar (Dasmo dkk, 2017).

Menurut Uno (2014), motivasi dapat diartikan sebagai dorongan internal dan eksternal dalam diri seseorang yang diindikasikan dengan adanya hasrat dan minat, dorongan dan kebutuhan, harapan dan cita-cita, penghargaan dan penghormatan. Dalam kegiatan belajar, maka motivasi dapat dikatakan sebagai keseluruhan daya penggerak di dalam diri siswa yang menimbulkan kegiatan belajar, yang menjamin kelangsungan dari kegiatan belajar dan memberikan arah pada kegiatan belajar, sehingga tujuan yang dikehendaki oleh subjek belajar itu dapat tercapai (Sardiman, 2012). Motivasi siswa sangat memengaruhi hasil belajarnya. Siswa yang mempunyai motivasi yang tinggi akan dapat meningkatkan hasil belajar yang baik, sebaliknya siswa yang mempunyai motovasi yang rendah akan memengaruhi kualitas belajar siswa sehingga hasil belajarnya juga rendah (Supardi, 2012). Dalam kegiatan belajar, maka motivasi dapat dikatakan sebagai keseluruhan daya penggerak di dalam diri peserta didik yang menimbulkan kegiatan belajar, yang menjamin kelangsungan dari kegiatan belajar dan memberikan arah pada kegiatan belajar, sehingga tujuan pembelajaran dapat tercapai (Astuti \& Dasmo, 2016). Menurut Retariandalas (2017) motivasi belajar dapat memengaruhi hasil belajar siswa.

Pembelajaran matematika merupakan pembelajaran yang realistik, sehingga dibutuhkan strategi pembelajaran yang mampu mengubah paradigma siswa terhadap matematika (Farhan \& Retnawati, 2014). Inovasi dalam proses belajar mengajar salah satunya adalah inovasi yang bisa dilakukan oleh guru dalam penerapan berbagai jenis inovasi dalam pembelajaran, khususnya dalam pembelajaran matematika. Dengan menggunakan inovasi media CD pembelajaran mampu meningkatkan motivasi dan hasil belajar matematika.

\section{PENUTUP}

Berdasarkan hasil pembahasan dan analisis data, dapat disimpulkan bahwa (1) Penggunaan media CD pembelajaran dapat meningkatkan motivasi belajar matematika siswa tentang menentukan berbagai jaring-jaring bangun ruang sederhana. (2) Penggunaan media CD pembelajaran dapat meningkatkan hasil belajar matematika siswa tentang menentukan berbagai jaring-jaring bangun ruang sederhana. 
Formatif: Jurnal Ilmiah Pendidikan MIPA

Vol. 8, No. 2, Agustus 2018, pp. 101-110

p-ISSN: 2088-351X

e-ISSN: 2502-5457

DOI: http://dx.doi.org/10.30998/formatif.v8i2.2459

\section{DAFTAR PUSTAKA}

Apriyani, D. D. (2017). Pengaruh penggunaan media proyeksi terhadap hasil belajar matematika. Formatif: Jurnal Ilmiah Pendidikan MIPA, 7(2): 115-123.

Arsyad, A. (2000). Belajar dan Pembelajaran Konstekstual. Bandung: Tarsito.

Astuti, I. A. D. \& Bhakti, Y. B. (2018). Interactive learning multimedia based microsoft excel on the temperature and heat. Unnes Science Education Journal, 7(1), 1-6.

Astuti, I. A. D. \& Dasmo. (2016). Upaya meningkatkan motivasi belajar dan pemahaman konsep IPA peserta didik dengan model pembelajaran problem posing. Jurnal Riset dan Kajian Pendidikan Fisika, 3(2), 39-44.

Bhakti, Y. B. (2017). Evaluasi program model CIPP pada proses pembelajaran IPA. JIPFRI (Jurnal Inovasi Pendidikan Fisika Dan Riset Ilmiah), 1(2), 75-82.

Dasmo, Astuti, I. A. D., \& Nurullaeli. (2017). Pengembangan pocket mobile learning berbasis android. Jurnal Riset dan Kajian Pendidikan Fisika, 4(2), 71-77.

Farhan, M., \& Retnawati, H. (2014). Keefektifan PBL dan IBL ditinjau dari prestasi belajar, kemampuan representasi matematis, dan motivasi belajar. Jurnal Riset Pendidikan Matematika, 1(2), 227-240.

Handhika, J. (2012). Efektivitas media pembelajaran IM3 ditinjau dari motivasi belajar. Jurnal Pendidikan IPA Indonesia, 1(2), 109-114.

Retariandalas, R. (2017). Pengaruh minat membaca dan motivasi belajar terhadap prestasi belajar IPA siswa. Formatif: Jurnal Ilmiah Pendidikan MIPA, 7(2): 190-197.

Safitri, M., Hartono, Y., \& Somakim, S. (2017). Pengembangan media pembelajaran matematika pokok bahasan segitiga menggunakan macromedia flash untuk siswa kelas VII SMP. Jurnal Pendidikan, 14(2), 62-72.

Sahrudin, A. (2014). Implementasi strategi pembelajaran discovery untuk meningkatkan kemampuan pemecahan masalah matematis dan motivasi belajar siswa SMA. JUDIKA (Jurnal Pendidikan Unsika), 2(1), 1-12.

Sardirman. (2012). Interaksi dan Motivasi Belajar Mengajar. Jakarta: Rajawali Pers.

Santrock, J.W. (2014). Psikologi Pendidikan. Jakarta: Salemba Humanika.

Siagian, R. E. F. (2012). Pengaruh minat dan kebiasaan belajar siswa terhadap prestasi belajar matematika. Formatif: Jurnal Ilmiah Pendidikan MIPA, 2(2), 122-131.

Supardi, U. S. (2012). Pengaruh pembelajaran matematika realistik terhadap hasil belajar matematika ditinjau dari motivasi belajar. Cakrawala Pendidikan, 31(2), 244-255.

Uno, H. B. (2014). Teori Motivasi dan Pengukurannya. Jakarta: Bumi Aksara.

Wulandari, F. R. A., Dewi, N. R., \& Akhlis, I. (2013). Pengembangan CD interaktif pembelajaran IPA terpadu tema energi dalam kehidupan untuk siswa SMP. Unnes Science Education Journal, 2(2), 262-268. 